\title{
STUDENTS' POSITIONAL IDENTITY IN WRITING ENGLISH
}

\author{
Riya Risqi Setyaningrum ${ }^{1)}$ \\ ${ }^{1}$ Teacher Training and Education Faculty, Universitas Islam Lamongan, Lamongan \\ E-mail: $\underline{{ }^{1} \text { riyarisqi@ unisla.ac.id }}$
}

Submitted: 24-09-2020

Accepted: 29-11-2020

DOI: https://doi.org/10.22202/tus.2020.v6i1.4352

\begin{abstract}
Writing is the most difficult in English. The students have to master their vocabulary and grammar to make their writing correct. The Indonesian students have to study hard in writing English. In learning writing English, the students' position have themselves as good writer and bad writer based on ethnicity, economic statues, gender, age, and education. This study is presented to know the students' positional identity in writing English. The data of studies are students' writing English and interviews. Those are elaborated descriptively. It means that this study is a case of study. The samples of study are the students of second semester of English Education Department at Lamongan Islamic University and Billfath University. It consists of 40 students from both niversity. The finding shown most of students positioned their identity in writing English as bad writer identity based on economic status and education. Therefore, teachers have to think hard the strategies in teaching writing to improve the students' identity in writing English.
\end{abstract}

Keywords: Identity, Positional identity, Writing

\section{INTRODUCTION}

English as a foreign language is very difficult to master. It means in teaching English foreign language is very difficult. Teaching English is very important (Rachman \& Margana, 2020). The teacher has to struggle in teaching English skill. One of the important skills in learning English is writing. It is a productive skill that the writer creates new language. As a productive skill, writing requires the teachers ask the students to produce a written work by using several elements of skills like using suitable words, worthy sentences and correct spelling (Hasibuan, 2013). It is the reason why English is very difficult. The difficulty is not only in producing and organizing ideas but also in translation the ideas into readable text (Herdi, 2000). In writing, definitely people have more time to think about what they want to say in writing than what they want to say in speaking. English is not only speech, but also writing produces language that the learner can express their thoughts. It has a position in language teaching since its 
acquisition involves a practice and knowledge of other skills, likes listening, reading and speaking (Klimova, 2012). Writing helps people to convey the ideas, solve problem and explore the worlds. But as we know, writing is not as easy as reading and listening in English. It is more difficult than others because in writing English the people have to master grammar and vocabulary. Both are the important things in learning writing. Grammar is ways that words can change their forms and combined into good sentences in that language (Harmer, 2002). Sameness with vocabulary, it is an indispensable constituent of language that constantly been a major area of interest within field of English language teaching (Darmawan, 2019). The people need more time to learn writing in English to make it correct. The people who write English correctly is called as someone who is well educated, an effective communicator and good performances.

Indonesian people are non-native speaker in English. A native speaker is the domain on the language that every people can categorize sentences in grammatical terms (Ningsh, 2017). English has to be familiar with the process of writing, the elements of writing, and the features of writing in order to use the language appropriate and accurately. The Indonesian people have to familiarize themselves to writing English because English is the international language that all of the people in the worlds use it. As all of people know that English as international language is very important in Indonesia because English is an international language that is used by all people in the worlds and to communicate with people over the worlds (Lauder, 2008). All technology also uses it to communicate or to setting every items. So, right now English have been learned by students from kindergarten until university.

The students have been learning it since Kindergarten or the first time they join in school. Even more, international school uses English as their daily communication. That habituation is in order to make students easy to communicate in English as international language. But in small towns, only one or two school which uses English as main subject and use it as daily communication. Even, English as a local content provided only to meet the Indonesian curriculum. It means that all of the students in Indonesia do not know English since childhood. 
Instead, some school in villages do not give English lesson for the kindergarten students. It also happens to elementary school. English is not given to all of the school in Indonesia. In elementary curriculum, English lesson is just local content. Only international school and school in towns get English as their subject. Yet, English in junior and senior high school becomes compulsory subject.

In learning English, Indonesian students make various efforts to improve their English. The parents themselves are aware that English is the important language in this era. Parents in the worlds were conscious in penetrating globalisation era that their children must be master the English skills (Zein, 2017). So, parents asked their children to join in English course to improve their English skill, not only in speaking, but also writing. The other place to improve English skill is English school extracurricular. In this era, some of students improve their English skill by reading English books or searching in internet. Technology is also the good way to improve English skill, especially writing. The reason why they join in English course or extracurricular or others is they position themselves as bad learner. It means they are looking for their own identity. The students' positional identity is caused by several factors, such as ethnicity, economic status, gender, age, and education; it is the second reason why the students position themselves in good and bad identity. Identity is a personal character or personality. Every people identity their identity based on the quality of their life. Identity is a way to identify about how the learner change who we are and creates personal histories of our community's condition (Wenger, 1998). It means that identity is the way of people to understand who they are and the way how to resolve themselves.

There is a study states that helping tutorial in writing can help out the student and writers to develop their writing identity (Oliveira, 2016). Those are divided into three categories; "a) pressure and demands on writing identity in academia, b) consequences of refusing or resigning to demands and pressures, and c) dealing with the consequences of refusing and resigning and developing writing 
identity in the writing Center." It makes the students join in English Course to make them understand more by some professional English tutors. The students' identity development can increase our awareness of how English more and the culture has become an important component in the academic and professional expansion to all language learners and users (Park, 2013). Culture itself is one of casual factors that affect the students' identity in writing English. The students position themselves into good learner or bad learner in learning English. It is called as positional identity.

Positional identity is often a knotted formed outcome of the participant in the daily activity (Holland et al., 1998). It emerges as a representation of power and privilege, continually reproduced within the social and cultural construction of figured world. Neither student nor teacher may be given explicit instructions as to what role each play or the manner in which they play it, and yet in the school environment and home this positional identity is regularly produced (Elliot, 2012). The writer's chances, experiences, and encounters are designed, sustain, and restricted by the social economic and cultural factors that reflect different access to discourses and identify their position (Ivaniḉ, 1994). A study of Creating space for students to position themselves as writers through experiences with digital writing (2016) tells that one of subject says that "I position myself as a good writer depend on the subject I'm writing about. If I'm writing on animals it's probably going to be good and when I'm writing about math I'm an expert writer, thus position himself as a successful writer' (Zoch et al., 2016). It means that the students position their identity as expert, good or bad based on what topic they write. Differences in study in Writer Identity and ESL Learners states that generally, Mandy makes disappear from their discussion of writer identities such as the elements of access, ethnicity, race, dis/ability, and class that are related in the topics of identity (Fernsten, 2008).

The other study of positional identity comes from Frankel (2017) who conducted a case study which analyzed the students' positional identity as a poor reader. The subject of study is an urban high school in Southwestern United States that the participant selected based on the students in whole-class readings of the 
group text. The finding was taken up in different way in two spaces between Radi and Samantha. Radi has positioned himself and by others as a poor reader. While Samantha has positioned himself as a good reader and also in turn positioned by others that he is capable in reading (Frankel, 2017). It means that in positioning their identity both them assisted by other people's opinion.

Burgess and Ivaniḉ (2010) investigate the discourse contraction of the writer's identity that develops the categories, such as it distinguishes several aspects of writers' identity according to the timescales over which they develop and it proposes interrelationships among the different aspects. The finding shown that the framework they have presented is an attempt to do so in the context of understanding the construction of writer identity(Burgess \& Ivanič, 2010) with the consequences of refusing and resigning and developing writing identity in the writing Center." It makes the students join in English Course to make them understand more by some professional English tutors. The students' identity development can increase our awareness of how English more and the culture has become an important component in the academic and professional expansion to all language learners and users (Park, 2013). Culture itself is one of casual factors that affect the students' identity in writing English. The students position themselves into good learner or bad learner in learning English. It is called as positional identity.

Referring to the studies above, it can be concluded that students position themselves as experts or good or bad writers based on several factors that have elaborate above. So this study conducts to analyze the students' positional identity in writing English based on ethnicity, economic statues, gender, age, and education.

\section{METHODS}

It is a study that investigate the students' identity in writing English. The data of investigation are students' writing English and interviews. Data were taken by online because of pandemic. So depth-investigation was done by whatsapp application, google meeting and email. The data of analysis were elaborated by words and sentences. Therefore, case study is a type of research that used in the field of qualitative method (A. Biba Rebolj, 2013). 
The subjects of this study are 40 sampling of English education department of two Universities at Lamongan. There were 20 students from Lamongan Islamic University and 20 students from Billfath University. The second semester students of English Education Department are the students who gain advanced knowledge, so before start to learn more in writing English, the researcher wants to know how they positioned themselves in writing English. The study was done for second semester, but the final data were collected at the end of semester. It means on June 2020.

Depth-investigation is to know the students' positional identity according to themselves. The data are their story in literacy narratives and interview by whatsapp application, meeting by google meeting. The students' literacy narratives were documented to know the story of their experiences in learning writing English. The students' literacy narratives send to email because between researcher and students never met face-to-face. Creswell (2009) suggest that in record the information from documents and interviews, the researcher takes note because it helps to classify the documents and interview based on the types of data. So, this study use field note to documenting all the data. The students' positional identity were analyzed and classify based on this table,

Table 1. Students' Positional Identity

\begin{tabular}{|c|c|c|c|c|c|c|c|c|}
\hline No & Respondent & $\begin{array}{c}\text { Positional } \\
\text { Identity }\end{array}$ & \multicolumn{5}{|c|}{ Category } \\
\cline { 3 - 9 } & & Good & Bad & Ethnicity & $\begin{array}{c}\text { Economic } \\
\text { Status }\end{array}$ & Gender & Age & Education \\
\hline 1 & & & & & & & & \\
\hline 2 & & & & & & & & \\
\hline 3 & & & & & & & & \\
\hline 4 & & & & & & & & \\
\hline
\end{tabular}

(Pettit \& Sugawara, 2002)

In order to get the validating the accuracy data this study following Creswell (2009); 1) Raw data (students' writing literacy narratives, fieldnotes, data interview). 2) The researcher organizes and prepares the data to analyse. This involves copying the interview, scanning material, makes field notes or sorting and arranging the data based on the classification of positional identity. 3) Read 
all of the data is in order to know the information from the students sharing in writing. 4) Coding is the main process in organizing the data. 5) Interrelating Description all the data from the coding. 6) Interpreting the description of data. To make it clear, see the graphic below,

\section{Graphic 1. Validating the data by Creswell (2009)}

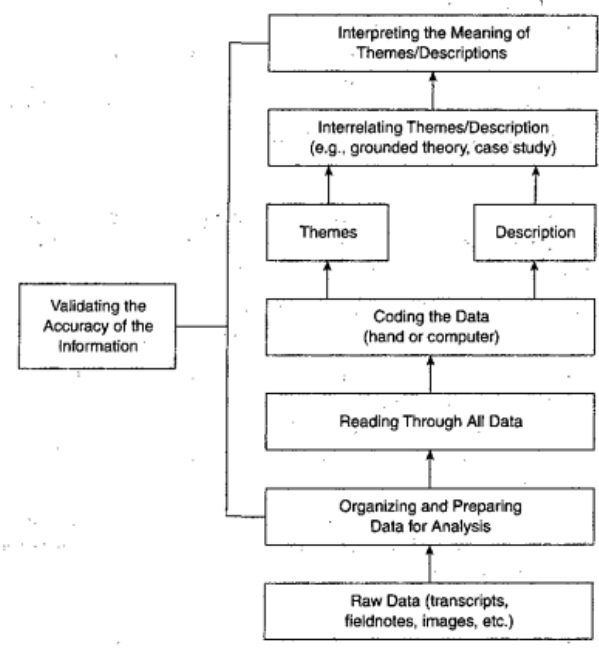

The study analyse 40 students' writing literacy narratives. The data were shown on the table, there was only taken some sample to describe. The study only took 2 samples of students' identity from each University.

\section{FINDING AND DISCUSSION}

Addressing to the research question about how students position themselves in writing English. The researcher attempts to discover the students' positional identities through the students writing. The result showed that the students position themselves as expert or good or bad writer based on ethnicity, economic statues, gender, age, and education. It was shown below:

\section{Table 1. Students' Positional Identity of Unisla}

\begin{tabular}{|c|c|c|c|c|c|c|c|c|}
\hline \multirow{2}{*}{ No } & \multirow{2}{*}{$\begin{array}{c}\text { responde } \\
\text { nt }\end{array}$} & \multicolumn{2}{|c|}{$\begin{array}{c}\text { Positional } \\
\text { Identity }\end{array}$} & \multicolumn{5}{|c|}{ Category } \\
\cline { 3 - 9 } & Good & Bad & Ethnicity & $\begin{array}{c}\text { Economic } \\
\text { statues }\end{array}$ & Gender & Age & Education \\
\hline 1 & A & & $\sqrt{ }$ & & $\sqrt{ }$ & & $\sqrt{ }$ \\
\hline 2 & B & $\sqrt{n}$ & & & $\sqrt{ }$ & & $\sqrt{ }$ \\
\hline 3 & C & & $\sqrt{ }$ & $\sqrt{ }$ & & & & $\sqrt{ }$ \\
\hline 4 & D & & $\sqrt{ }$ & & $\sqrt{ }$ & $\sqrt{ }$ & $\sqrt{ }$ \\
\hline 5 & E & & $\sqrt{ }$ & & & $\sqrt{ }$ & \\
\hline
\end{tabular}




\begin{tabular}{|c|c|c|c|c|c|c|c|c|}
\hline 6 & $\mathrm{~F}$ & $\sqrt{ }$ & & & & $\sqrt{ }$ & $\sqrt{ }$ & $\sqrt{ }$ \\
\hline 7 & $\mathrm{G}$ & & $\sqrt{ }$ & & $\sqrt{ }$ & & & $\sqrt{ }$ \\
\hline 8 & $\mathrm{H}$ & & $\sqrt{ }$ & $\sqrt{ }$ & $\sqrt{ }$ & & & $\sqrt{ }$ \\
\hline 9 & $\mathrm{I}$ & & $\sqrt{ }$ & $\sqrt{ }$ & $\sqrt{ }$ & & & \\
\hline 10 & $\mathrm{~J}$ & & $\sqrt{ }$ & & $\sqrt{ }$ & & & \\
\hline 11 & $\mathrm{~K}$ & & $\sqrt{ }$ & & $\sqrt{ }$ & & & $\sqrt{ }$ \\
\hline 12 & $\mathrm{~L}$ & & $\sqrt{ }$ & $\sqrt{ }$ & & & $\sqrt{ }$ & \\
\hline 13 & $\mathrm{M}$ & $\sqrt{ }$ & & $\sqrt{ }$ & $\sqrt{ }$ & & & $\sqrt{ }$ \\
\hline 14 & $\mathrm{~N}$ & $\sqrt{ }$ & & & $\sqrt{ }$ & & $\sqrt{ }$ & $\sqrt{ }$ \\
\hline 15 & $\mathrm{O}$ & $\sqrt{ }$ & & & $\sqrt{ }$ & & & $\sqrt{ }$ \\
\hline 16 & $P$ & $\sqrt{ }$ & & $\sqrt{ }$ & $\sqrt{ }$ & & & $\sqrt{ }$ \\
\hline 17 & $\mathrm{Q}$ & $\sqrt{ }$ & & & $\sqrt{ }$ & & & $\sqrt{ }$ \\
\hline 18 & $\mathrm{R}$ & & $\sqrt{ }$ & & & $\sqrt{ }$ & & $\sqrt{ }$ \\
\hline 19 & $\mathrm{~S}$ & $\sqrt{ }$ & & & $\sqrt{ }$ & & & $\sqrt{ }$ \\
\hline 20 & $\mathrm{~T}$ & & $\sqrt{ }$ & $\sqrt{ }$ & & & $\sqrt{ }$ & $\sqrt{ }$ \\
\hline
\end{tabular}

Respondent $\mathrm{N}$ position herself as good writer in English because of economic statues, age and education. Since she was at elementary school the parent have support her to join in English course. The parents also enrolled her in English-based school. In addition to master speaking English, writing is also the important skill that must be master because some projects in class write in English. She has been joined in English course until senior high school. She told that;

[Respondent N] I think I'm a lucky as a child who has parent always support my academic. When I was elementary school, I think English is the very difficult. I always bored in class. My parents know that I am lack in English, so in the second grades my parents support me to join in English courses. My school also English-Based School, almost all of subject use English. Willy nilly I have to master my English skill since I was young. So I like English right now.

Dealing with her statement, by economic statues, age and education she can improve their English skill, especially in writing English. In this space, good writer identity is described well through her writing "Since I join in English course my English score in speaking and writing are good. I am more confidence in speaking or doing my assignment in English." The other evidence came from interview with her.

[Respondent N] My English teacher told me that my score is good enough. It makes me more confidence and excited to improve my English academic. My teacher's support is the reason why I want to be an English teacher. 
Differences with respondent $\mathrm{H}$, she positions herself as bad writer because of ethnicity, economic statues and education. At the first time she got English in in junior high school. The environment where she lives does not support her to learn English more. English is so difficult for her. She did not do some efforts to improve her English skill. Her parent's economic is not support too. She told,

[Respondent H] Since I got English in school I feel English is so difficult and bored. I never join in English course or extracurricular because my parent are not be able to pay the English course. My English score always got poor. It makes me lazier to study English. I cannot read English, even less writing English.

Connecting to a piece of quotation from writing above, it clearly point out that respondent $\mathrm{H}$ is regarded herself as poor writer. By stating that "I cannot read English, even less writing English", the positioning identity is obviously described. In this matter, it can be said that although he is a student, educating person, it is possible to have poor identity in writing English.

[Respondent H] As I have told before that my English is lack. It means that not only reading, speaking and listening, my writing also lack. So why I want to join in English Education Department is in order to improve my English skills. During one semester I feel my English skill have change, especially in writing. Even though, I am not a good writer yet.

The aforementioned quotation and interview above strongly told that English is not easy. In producing words in foreign language is very difficult because they never improve their vocabulary acquisition. The condition can be occurred by many reasons, like the environment where she live, her economy statues and where she was study.

Based on the data, ethnicity is the third position identity, and then followed by gender and ages. Positioning themselves in ethnicity means their ethnicity influences their English skills.

The second analysis comes from students' writing of second semester at Billfath University. Different with students' of English Education Department at Lamongan Islamic University, the most students categorize themselves in position identity; education and ethnicity.

They state that environment is the most influence in learning English. A place where they live is not support them to learn English. Their daily language is 
Javanese. So English considered is not important. Education and ethnicity are two things that very influences on the culture. Culture and language are interconnected. In understanding a language, the people need to understand the culture. In means to understand English language well, they need to live in good ethnicity and education. The data were shown below,

Table 2. Students' Positional Identity of Billfath University

\begin{tabular}{|c|c|c|c|c|c|c|c|c|}
\hline \multirow{2}{*}{ No } & \multirow{2}{*}{$\begin{array}{c}\text { Respon } \\
\text { dent }\end{array}$} & \multicolumn{2}{|c|}{$\begin{array}{l}\text { Positional } \\
\text { Identity }\end{array}$} & \multicolumn{5}{|c|}{ Category } \\
\hline & & Good & Bad & Ethnicity & $\begin{array}{c}\text { Economic } \\
\text { statues }\end{array}$ & Gender & Age & $\begin{array}{c}\text { Educat } \\
\text { ion }\end{array}$ \\
\hline 1 & A & & $\sqrt{ }$ & $\sqrt{ }$ & & & $\sqrt{ }$ & \\
\hline 2 & B & & $\sqrt{ }$ & & $\sqrt{ }$ & & & \\
\hline 3 & $\mathrm{C}$ & $\sqrt{ }$ & & & $\sqrt{ }$ & $\sqrt{ }$ & $\sqrt{ }$ & $\sqrt{ }$ \\
\hline 4 & $\mathrm{D}$ & & $\sqrt{ }$ & & $\sqrt{ }$ & & & \\
\hline 5 & $\mathrm{E}$ & & $\sqrt{ }$ & & $\sqrt{ }$ & $\sqrt{ }$ & & $\sqrt{ }$ \\
\hline 6 & $\mathrm{~F}$ & & $\sqrt{ }$ & $\sqrt{ }$ & & & & \\
\hline 7 & $\bar{G}$ & & $\sqrt{ }$ & & & $\sqrt{ }$ & & $\sqrt{ }$ \\
\hline 8 & $\mathrm{H}$ & & $\sqrt{ }$ & $\sqrt{ }$ & & & & \\
\hline 9 & I & & $\sqrt{ }$ & $\sqrt{ }$ & & & & \\
\hline 10 & $\mathrm{~J}$ & $\sqrt{ }$ & & & $\sqrt{ }$ & & & $\sqrt{ }$ \\
\hline 11 & K & & $\sqrt{ }$ & & & $\sqrt{ }$ & & $\sqrt{ }$ \\
\hline 12 & $\mathrm{~L}$ & & $\sqrt{ }$ & $\sqrt{ }$ & & & & \\
\hline 13 & $\mathrm{M}$ & $\sqrt{ }$ & & $\sqrt{ }$ & $\sqrt{ }$ & & & \\
\hline 14 & $\mathrm{~N}$ & & $\sqrt{ }$ & $\sqrt{ }$ & & & & $\sqrt{ }$ \\
\hline 15 & $\mathrm{O}$ & & $\sqrt{ }$ & $\sqrt{ }$ & & & & \\
\hline 16 & $\mathrm{P}$ & $\sqrt{ }$ & & & $\sqrt{ }$ & & & $\sqrt{ }$ \\
\hline 17 & $\mathrm{Q}$ & & $\sqrt{ }$ & 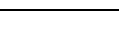 & & $\sqrt{ }$ & & $\sqrt{ }$ \\
\hline 18 & $\mathrm{R}$ & $\sqrt{ }$ & & $\sqrt{ }$ & $\sqrt{ }$ & & & $\sqrt{ }$ \\
\hline 19 & $\mathrm{~S}$ & $\sqrt{ }$ & & $\sqrt{ }$ & & & $\sqrt{ }$ & $\sqrt{ }$ \\
\hline 20 & $\mathrm{~T}$ & & $\sqrt{ }$ & $\sqrt{ }$ & & & & $\sqrt{ }$ \\
\hline
\end{tabular}

Respondent $\mathrm{C}$ is a student who interest in learning English since he was young. He positions himself as good writer because of economic status, gender, age and education. He states that as a man he has intelligence above the women. He uses it to explore his potential. The economic status of his parents is an effect to support his English skills. Respondent $\mathrm{C}$ reveals that his identity as good writer that showed in his sentence "My teacher is often asked me to write a short story or poetry or article and publish it into school magazine." It means that he had created several writing product.

[Respondent C] I like English since I was child. It caused my older sister is often teach me English vocabulary. Sometimes, I mention many objects by using English, like bird, giraffe, chair, door and others. Beside my older 
sister, my mom also teaches me some new vocabulary in English. Although I am not a native-speaker, in my house almost all member use English in some words. (Interview, 5/7/20).

The sentences and interview clearly showed that he was really a good writer that supported by economic statues and gender. He also positioned his identity in age and education. He stated that the level of man's maturity based on age. When the man got older, his intelligence increases. It showed in sentence, "when I was at elementary school, my English skill is ordinary. By adding my ages, my English skills have increase. Definitely, it is supported by my parents and a place where I school".

[Respondent C] I always feel confidence although I came from village. My ethnicity does not discourage me to improve my English skills, especially in writing. My parents said that as a man I have to be success. A man must study hard and work hard. So, wherever I go to course my parents always support me. My teacher in school is also support me. She is very intelligent and always gives me motivation to improve my English more.

The statement above shows that he has good supporter. His position identity has changed by changing his age and where he is going to study. For him, school is also very influence on his English language skills.

The last analysis is about bad writer identity. Students can express what they feel and experience in studying English. There are fourteen students who position themselves as bad writer. One of finding is interesting. Confidently, the respondent E states that "I love to write, my feeling in English is good." She said,

[Respondent E] Since junior high school I begin to love English. I like to write diary, short story or others. I'm very lucky among my friends who become comic lovers. When we are gathering, they share about the book that they have read. In that time, I always get idea to write because my written based on their stories."(Interview5/7/20)

The sentence written by respondent $\mathrm{E}$ shows that she is the only different from other students in positional identity in low level. The interview script and writing shows that she positions herself as good writer. But uniquely, she confirms than that time by time she reads more books then she realizes that her writing is not good enough. It's revealed in her sentence, "At second grade of Junior high school my friends affect me to read story book. When I read more, I realized that my writing still far from good. It means I am not good writer". 
[Respondent E] I'm very happy to write. I think writing is how to train our brain to be creative. Not only that, to improve my writing skill I study hard to understand more about grammar and improve my vocabulary. But, since I also like read book, I realize that my writing is not as good as the book I have read. I ever tried several times to include my work on teen magazines, but none has ever been accepted. It is evidence that my writing is bad. (Interview, $5 / 7 / 20$ )

The first statement of respondent $\mathrm{E}$ reveals that writing is pleasure and she loves doing it which can be seen as her positional identity as a good writer. But then in her last part of his writing, she states that her writing skill is not quite well. It seems as a result of a process in finding self-identity. She positions herself as good writer but after several activities she finds that she is not more than bad writer.

In this case, identity can be found when someone realizing her level in writing English. Subject E is the only one student who shares this condition which is her positional identity is change after she realizing her skill.

From all of the positional identity of students writing English, the interesting finding is that almost all students state that economic statues and education is more affects their positional identities. The finding of study is more than $50 \%$ of students have position themselves as bad writers. It means that the students' writing in English is lack. They state that writing in English is very difficult.

Considering the finding above writing is a place to express the people ideas that look easy but in fact it is very difficult. Moreover, writing in English as a foreign language. The writers must be aware to grammar and vocabulary. The writers who use incorrect grammar induces to misunderstanding and the writers have to master too many vocabularies because in English a word has many meanings and the meaning changes according to the context, phenomena makes learning process even more challenging (Mohammed, 2018).

Based on the students' sharing in writing, they share their positional identity. The positional identity divided into two; good writer and bad writer. Ferbsten (2008) states that "Good writer" and "Bad writers" are subject positions common to writing classes (Bronwyn T Williams, 2003; Idriz F et.al, 2012; 
Schultz \& Bob Fecho, 2010). Good and bad writer based on five categories; ethnicity, economic statues, gender, age and education.

First, the finding discussed the students' positional identities considering the students of second semester writing at Lamongan Islamic University and Billfath. Here, the lecture asked them to share their positional identity and the reason why the position themselves as a good writer or bad writer. It is found that most of students positioned themselves as a bad writer. Writing seemingly becomes the most problematic skills for students because they have to find ideas or topic. They have position themselves as good writer and poor writer based on five categories. There are only fourteen students from two Universities who position themselves as good writer. The claim is vary in many reasons such as presented by respondent $\mathrm{N}$ from Lamongan Islamic University, she positioned herself as good writer because the economic statues, age and education. A student from Billfath University has position himself as good reader because of economic statues, gender, age and education. It means both agree that economic statues and education are the most factors which affect their identity. A study has represent education plays a significant role in achieving a good quality of life (Idris et al., 2012). Education affects the people to positioning identity.

Second, the finding showed that several students were positioned themselves as bad writers. Their identity is also based on five categories that every student categorizes themselves into more than one. Several studies have focused on how students position themselves (Leander, 2002; Clarke, 2006). An economic statue is one of the most categories that affect students' identity. In fact there are the important of relationship between class level, students' evidences and views; the financial wealth helps the students' improve their English skill (Salameh \& Sathakathulla, 2018). Two students who had been interviewed said that they could change their identity as good writer because their economic statues. One student from Billfath University said that she positioned herself as good writer but after she learned more, she realized that her writing is not correct. Then she positioned herself as bad writer. 
Considering the finding above found that there were only a bit students who were categorized their identity based on age and gender. They stated that gender and age were not problems in raising their identity.

\section{CONCLUSION}

This study reveals the students' positioning identity in writing English. The study identifies the reflection of students' story in writing. It needs underlined that every student position themselves as good or bad writer based on more than one category. The result shows that the most categories who affect the students' positioning identity as good writers and bad writers are ethnicity, economic statues and education. There are eight students at Lamongan Islamic University who position themselves as good writer based on; two in ethnicity, seven in economic statues, two in gender, one in age, and eight in education. There are twelve students who positioned themselves as bad writers followed categories; five in ethnicity, seven in economic statues, two in gender, three in ages, eight in education. It means education is the most categories in positioning identity.

The second analysis that happened at Billfath University shows that there are six students who positioned themselves as good writers and fourteen students as bad writers. The students who positioned themselves as good writer followed; three in ethnicity, five in economic statues, one in gander, two in ages, and five in education. Then the students who position themselves as bad writer followed; eight in ethnicity, three in economic statues, four in gender, one in age, and six in education. Considering the analysis of students' positioning identity at Billfath University shown that most of the students positioned themselves as bad writers which the most categories is ethnicity.

\section{ACKNOWLEDGMENT}

The researcher would like to say thank you to Research Directorate and Public Devotion, General Directorate of Strengthening Research and Development, Ministry of Research, Technology and Higher Education who has funded this research appropriate with the Beginner Lecturer Research Contract in the years 2020 . 


\section{REFERENCES}

A. Biba Rebolj. (2013). The case study as a type of qualitative research. Journal of Contemporary Educational Studies, 1(2013), 28-43. https://www.researchgate.net/publication/265682891

Bronwyn T Williams. (2003). Heroes Rebels and Victims; Student identities in Literacy Narratives. Journal of Adolescent \& Adult Literacy, 47(4), 342-345.

Burgess, A., \& Ivanič, R. (2010). Writing and being written: Issues of identity across timescales. Written Communication, 27(2), 228-255. https://doi.org/10.1177/0741088310363447

Darmawan, D. (2019). The Effect of Story Reading on Incidental Lexical and Grammatical Collocation LEarning. Beyond Words, 53(9), 1689-1699. https://doi.org/10.1017/CBO9781107415324.004

Elliot, M. L. (2012). Figured world of eating disorders: Occupations of illness. Canadian Journal of Occupational Therapy, 79(1), 15-22. https://doi.org/10.2182/cjot.2012.79.1.3

Fernsten, L. A. (2008). Writer Identity and ESL Learners. Journal of Adolescent \& Adult Literacy, 52(1), 44-52. https://doi.org/10.1598/jaal.52.1.5

Frankel, K. K. (2017). What Does It Mean to Be a Reader? Identity and Positioning in Two High School Literacy Intervention Classes. Reading and Writing Quarterly, 33(6), 501-518. https://doi.org/10.1080/10573569.2016.1250143

Harmer, J. (2002). The Practice of English Language Teaching (Third Edition) (Third Edit). Longman. https://doi.org/10.1093/elt/57.4.401

Hasibuan, K. (2013). Teaching Writing as Productive Skills. Journal of English and Arabic Language Teaching, 2, 1-22. https://media.neliti.com/media/publications/244085-teaching-writing-asproductive-skills-8b60050c.pdf

Herdi, H. (2000). an Analysis on Factors Influencing the Students '. Journal of Lancang Kuning, 14(2), 19-22.

Holland, D., Jr, W. lachicotte, Skinner, D., \& Cain, C. (1998). Identity and Agency in Cultural Worlds. In Choice Reviews Online (Vol. 36, Issue 10). https://doi.org/10.5860/choice.36-5759

Idris, F., Hassan, Z., Ya'acob, A., Gill, S. K., \& Awal, N. A. M. (2012). The Role of Education in Shaping Youth's National Identity. Procedia - Social and Behavioral Sciences, 59 , 443-450. https://doi.org/10.1016/j.sbspro.2012.09.299 
Klimova, B. F. (2012). The Importance of Writing. Paripex - Indian Journal Of Research, 2(1), 9-11. https://doi.org/10.15373/22501991/jan2013/4

Lauder, A. (2008). the Status and Function of English in Indonesia: a Review of Key Factors. Makara Human Behavior Studies in Asia, 12(1), 9. https://doi.org/10.7454/mssh.v12i1.128

Leander, K. M. (2002). Locating Latanya: The Situated Production of Identity Artifacts in Classroom Interaction. Research in the Teaching of English, 37(2), 198-250. http://www.jstor.org/stable/40171622

Mohammed, M. H. (2018). Challenges of Learning English As a Foreign Language ( Efl ) By Non-Native Learners. International Journal of Social Science and Economic Research, 3(04), 1380-1400. www.ijsser.org

Ningsh, N. (2017). Native Speaker in Teaching English To Indonesian Students At Icp Fmipa Unm. ETERNAL (English, Teaching, Learning and Research Journal), 3(1), 12-24. https://doi.org/10.24252/eternal.v31.2017.a2

Oliveira, D. (2016). The Development of Writing Identity through Writing Center Tutorial. 3, 27-48.

Park, G. (2013). Writing is a way of knowing': Writing and identity. ELT Journal, 67(3), 336-345. https://doi.org/10.1093/elt/cct012

Pettit, R. W., \& Sugawara, A. I. (2002). Age, gender, socioeconomic status, race/ethnicity, temperament, and actual social and cognitive competence as factors contributing to preservice teachers' perceptions of preschool children's social and cognitive competence). Journal of Early Childhood Teacher Education, 23(2), 125-136. https://doi.org/10.1080/1090102020230204

Rachman, S. M., \& Margana. (2020). Developing English Speaking Materials Oriented to Brain Accommodation. 6(1), 1-12. https://doi.org/https://doi.org/10.22202/tus.2020.v6i1.2939 Abstract

Salameh, W., \& Sathakathulla, A. A. (2018). The Impact of Social-Economic Factors on Students' English Language Performance in EFL Classrooms in Dubai. English Language and Literature Studies, 8(4), 110. https://doi.org/10.5539/ells.v8n4p110

Wenger, E. T. I. (1998). Communities of Practice: Learning, Meaning, and Identity (Issue 770558400). Cambridge University Press. https://doi.org/10.1080/17439760600613685

Zein, M. S. (2017). Elementary English education in Indonesia: Policy developments, current practices, and future prospects. English Today, 33(1), 53-59. https://doi.org/10.1017/S0266078416000407 
Zoch, M., Adams-Budde, M., \& Langston-Demott, B. (2016). Creating Spaces for Students to Position Themselves as Writers through Experiences with Digital Writing. Texas Journal of Literacy Education, 4(2), 111-125. https://files.eric.ed.gov/fulltext/EJ1121643.pdf 